\title{
Effect of Drip Fertigation on the Productivity of Hybrid Rice
}

\author{
T. Ramesh ${ }^{* 1}$, S. Rathika ${ }^{1}$, E. Subramanian ${ }^{2}$ and V. Ravi ${ }^{3}$ \\ ${ }^{1}$ Department of Agronomy, Anbil Dhamalingam Agricultural College and Research Institute, Tiruchirappalli-620 027, India \\ ${ }^{2}$ Department of Agronomy, Agricultural College and Research Institute, Madurai-624 104, India \\ ${ }^{3}$ Tamil Nadu Rice Research Institute, Aduthurai-612 001, Tamil Nadu, India
}

* Corresponding author: agronramesh@gmail.com (ORCID ID: 0000-0001-9869-9515)

Paper No. 840

Received: 22-12-2019

Revised: $15-04-2020$

Accepted: 28-05-2020

\begin{abstract}
A field experiment was conducted at Tamil Nadu Rice Research Institute (TRRI), Tamil Nadu Agricultural University, Aduthurai to standardize lateral spacing, plant row spacing, fertilizer levels and source of fertilizers on the productivity of hybrid rice under drip irrigation. The experiment was conducted in strip plot design with replicated thrice. Main plot treatments were two lateral spacing (80 and $100 \mathrm{~cm}$ ) with two plant row spacing (uniform row spacing and modified row spacing). In $80 \mathrm{~cm}$ lateral spacing, uniform row spacing of $20 \times 10 \mathrm{~cm}$ and modified row spacing of $7.5 \times 20 \times 25 \times 20 \times 7.5 \mathrm{~cm}$ were adopted. In case of $100 \mathrm{~cm}$ lateral spacing, uniform row spacing of $20 \times 10 \mathrm{~cm}$ and modified row spacing of 7.5 $\times 15 \times 15 \times 25 \times 15 \times 15 \times 7.5 \mathrm{~cm}$ were adopted. In sub plots, combination of two fertilizer levels (75 and 100\% RDF) and two sources of fertilizers (common fertilizers - urea, single super phosphate and muriate of potash and water soluble fertilizers - urea, mono ammonium phosphate and sulphate of potash) were used for fertigation. Short duration hybrid CORH 3 was used.

Results revealed that lateral spacing at $80 \mathrm{~cm}$ with modified row spacing $(7.5 \times 20 \times 25 \times 20 \times 7.5 \mathrm{~cm})$ produced significantly taller plants $(76.1 \mathrm{~cm})$, more number of leaves per hill $(74.9 /$ hill $)$ and tillers population (625 per $\mathrm{m}^{2}$ ), higher root growth parameters at maximum tillering stage viz., root length (18.5 $\mathrm{cm})$, root volume (13.1cc) and root dry weight (6.2g), higher yield attributes like productive tillers (453/ $\mathrm{m}^{2}$ ), number of filled grains per panicle(124.9) and higher grain yield of $5055 \mathrm{~kg} / \mathrm{ha}$ than lateral spacing of $100 \mathrm{~cm}$ with modified row spacing. Fertigation with different levels and sources of fertilizers revealed that application of $100 \%$ recommended dose of fertilizers (RDF) as water soluble fertilizer produced significantly higher growth, yield parameters and grain yield of $4230 \mathrm{~kg} /$ ha over $75 \%$ RDF. However, it was comparable with $100 \%$ RDF as conventional fertilizers.

\section{Highlights}

(0 Growing of rice hybrid CORH 3 under drip irrigation using $80 \mathrm{~cm}$ lateral spacing, modified row spacing $(7.5 \times 20 \times 25 \times 20 \times 7.5 \mathrm{~cm})$ and fertigation of $100 \%$ RDF either as conventional or water soluble fertilizers found to increase the productivity of hybrid rice.
\end{abstract}

Keywords: Drip fertigation, Lateral spacing, Plant row spacing, , Hybrid rice, Water soluble fertilizers

Rice (Oryza sativa L.) is one of the most important food crops in the world. In Asia, more than two billion people are getting $60-70 \%$ of their food energy from rice and its derived products. It is the dominant irrigated crop, accounting $30 \%$ or more of the total irrigated area and taking up more than two-thirds of the available water supply for agriculture, in many Asian countries (Barker et al. 1999). India is the world's second largest producer of rice. It is cultivated over an area of 44.2 million ha, which is about $50 \%$ of the total irrigated agriculture area of the country (Anon, 2016). Rice consumes around 5000 liters of water to produce one $\mathrm{kg}$ of grain, which is three times higher than other cereals (Belder et al. 2004). Recently, more riceproducing countries are facing water scarcity now than ever before, which threatens the sustainability of irrigated rice ecosystem. 
The present and future food security of Asia and India depends upon the irrigated rice production system. Irrigated rice crop uses high amount of water because the crop is grown under low land condition, the soil is puddle and the field is kept flooded with 3 to $5 \mathrm{~cm}$ depth of water after transplanting until 10 days before harvest. As the demand for water for domestic, municipal, industrial and environmental purposes rise in the future, less and less water would be available for irrigation. Water availability for agriculture in India which is $83.3 \%$ of total water used today, will shrink to $71.6 \% 2025$ and to $64.6 \%$ in 2050 , indicated by the Ministry of Agriculture, Government of India. To safeguard food security and preserve precious water resources, ways must be explored to grow more rice with less water (Belder et al. 2002). In addition, cultivation of paddy using bore well / filter points leads over exploitation of ground water as paddy consumes more water and improper water management practices causes increasing of salt affected soils.

These situations force to produce more rice with less water to ensure the food security of India where water scarcity for agricultural use is increasing. One of the approaches that lead to a considerable amount of water saving in rice production is drip irrigation. It is fundamentally different approach to reduce water use in rice cultivation where rice is grown as irrigated dry upland crop (Ottis et al. 2006). It is considered as an alternative irrigation approach for better water and fertilizer use efficiency (Assouline 2002; Hanson \& May 2003; Eid et al. 2013). Drip irrigation is a promising system for economizing on the available irrigation water. Preliminary studies in some countries suggested that drip irrigation has the potential for large water savings compared to conventionally flooded rice production. There is growing interest in adopting drip irrigation in rice in several countries with the yield levels ranging of 6-8 t/ha (Medley and Wilson, 2008). Anusha and Nagaraju (2015) compared rice genotypes under drip irrigation with conventional transplanted system and found that across genotypes drip irrigated rice recorded significantly higher yield $7934 \mathrm{~kg} / \mathrm{ha}, 19 \%$ higher than that of conventional flood system $(6659 \mathrm{~kg} / \mathrm{ha})$, resulted in $58 \%$ water saving. Water productivity was highest under drip $(11.80 \mathrm{~kg} / \mathrm{ha} \mathrm{mm})$ as compared to transplanted rice
(4.17 kg/ha mm). Besides water saving, precise nutrient management through fertigation with drip irrigation can reduce overall fertilizer application rates and minimize adverse environmental impact. Researchers have demonstrated drip-irrigated crop response to $\mathrm{N}$ fertilizer with higher water use efficiency (Wang et al. 2009). Keeping all this in view, the present study was carried out to study the effect of lateral spacing, plant row spacing, levels and source of fertilizers on the growth, yield parameters and productivity of drip irrigated rice

\section{MATERIALS AND METHODS}

A field experiment was conducted at Tamil Nadu Rice Research Institute (TRRI), Tamil Nadu Agricultural University, Aduthurai to study the effect of lateral spacing, plant row spacing, fertilizer levels and source of fertilizers on the productivity of drip irrigated rice. The experimental site TRRI, Aduthurai is present in the middle of the Cauvery Delta Zone, Tamil Nadu, India, geographically located at $11^{\circ} \mathrm{N}$ latitude $79.3^{\circ}$ E longitude with an altitude of $19.4 \mathrm{~m}$ above MSL. The soil of the experimental field was alluvial clay with $\mathrm{pH}$ of 7.5 and EC of $0.3 \mathrm{dS} / \mathrm{m}$ and low, high and medium in available nitrogen, phosphorus and potassium contents respectively. The experiment was conducted in strip plot design with replicated thrice. Main plot treatments consisted of two lateral spacing $(80$ and $100 \mathrm{~cm})$ with two plant row spacing (uniform row spacing and modified row spacing). In $80 \mathrm{~cm}$ lateral spacing uniform row spacing of $20 \times 10 \mathrm{~cm}$ and modified row spacing of $7.5 \times 20 \times 25 \times 20 \times 7.5 \mathrm{~cm}$ were adopted. In case of $100 \mathrm{~cm}$ lateral spacing, uniform row spacing of $20 \times 10 \mathrm{~cm}$ and modified row spacing of $7.5 \times$ $15 \times 15 \times 25 \times 15 \times 15 \times 7.5 \mathrm{~cm}$ were adopted. Number of plant rows irrigated by $80 \mathrm{~cm}$ lateral spacing was four rows. Whereas, in $100 \mathrm{~cm}$ lateral spacing, it was five rows in uniform spacing and six rows in modified row spacing. In sub plots, combination of two fertilizer levels (75 and 100\% RDF) and two sources of feriltizers (common fertilizers - urea and muriate of potash and water soluble fertilizers - mono ammonium phosphate and sulphate of potash) were used for fertigation.

Short duration hybrid CORH 3 was used. Manual sowing of seeds was done in the finely prepared dry soil. Drip system was installed with the lateral spacing of $80 \mathrm{~cm}$ and $100 \mathrm{~cm}$ and emitter/dripper 
spacing of $30 \mathrm{~cm}$. Discharge rate of drippers was 1.0 litre per hour. Irrigation was given at $150 \%$ Pan Evaporation during throughout the cropping period in every alternate day. Recommended dose of fertilizer (150: 50:50 kg NPK/ha) was adopted. The entire $\mathrm{P}$ as SSP was applied as basal during land preparation. The $\mathrm{N}$ as urea and $\mathrm{K}$ were given in 15 splits starting from 14 DAS to heading stage at 5 days interval along with irrigation water. Observations on growth and yield attributing characters and grain yield of rice, water usage were recorded. Water productivity was worked out by dividing the grain yield with total water used for crop. Data on various characters studied during the course of investigation was statistically analysed with the confidence level set at $5 \%$ was used to compare the differences among treatment means (Gomez and Gomez 1984).

\section{RESULTS AND DISCUSSION}

\section{Growth parameters}

Growth parameters of drip irrigated rice significantly varied due to lateral spacing, row spacing and fertigation treatments (Table 1). Lateral spacing at $80 \mathrm{~cm}$ with modified row spacing $(7.5 \times 20 \times 25 \times$ $20 \times 7.5 \mathrm{~cm})$ produced significantly taller plants $(76.1 \mathrm{~cm})$, more number of leaves per hill (74.9/ hill) and tillers population ( 625 per $\mathrm{m}^{2}$ ) than lateral spacing of $100 \mathrm{~cm}$ with modified row spacing $(7.5 \times$
$15 \times 15 \times 25 \times 15 \times 15 \times 7.5 \mathrm{~cm})$. However, this was comparable with uniform row spacing in both 80 and $100 \mathrm{~cm}$ lateral spacing. This was mainly due to uniform water availability to all the rows under modified row spacing. Lateral spacing at $80 \mathrm{~cm}$ with uniform row spacing $(20 \times 10 \mathrm{~cm})$ registered higher plant height of $73.9 \mathrm{~cm}$, number of leaves per hill (70.4) and tillers population of 602 per $\mathrm{m}^{2}$. Uniform row spacing in $80 \mathrm{~cm}$ lateral spacing produced more tillers over $100 \mathrm{~cm}$ lateral spacing because of higher water available to all the four rows over 100 $\mathrm{cm}$ lateral spacing where the fifth row present in the middle received less water. Minimum growth parameters of rice viz., plant height $(71.4 \mathrm{~cm})$ and leaves per hill (60.2) were recorded with lateral spacing of $100 \mathrm{~cm}$ with modified row spacing.

Among the fertigation treatments, application of $100 \%$ RDF as soluble fertilizers recorded significantly taller plants $(74.7 \mathrm{~cm})$, more numbers of leaves per hill (71.7/hill) and tillers population $\left(660\right.$ per $\left.\mathrm{m}^{2}\right)$ than $75 \%$ RDF irrespective of sources. However, it was on par with $100 \%$ RDF as conventional fertilizers which registered plant height of $73.6 \mathrm{~cm}$, number of leaves per hill of 71.4 and tillers population of $634 / \mathrm{m}^{2}$. Availability of more phosphorus from water soluble fertilizer (MAP) favoured production of more tillers. The enhancement of growth parameters might be due to the uniform wetting area and root zone application of nutrients through drip system coupled with constant and continuous availability

Table 1: Effect of lateral, plant row spacing, fertilizer levels and sources on growth parameters of drip irrigated rice

\begin{tabular}{|c|c|c|c|c|}
\hline \multirow[b]{2}{*}{ Treatments } & \multicolumn{3}{|c|}{ Growth parameters } & \multirow{2}{*}{$\begin{array}{l}\text { - Leaf chlorophyll } \\
\text { (SPAD value) }\end{array}$} \\
\hline & $\begin{array}{l}\text { Plant height } \\
\text { (cm) }\end{array}$ & $\begin{array}{l}\text { No. of leaves } \\
\text { per hill }\end{array}$ & $\begin{array}{l}\text { Tillers } \\
\text { population } \mathbf{m}^{-2}\end{array}$ & \\
\hline \multicolumn{5}{|l|}{ Main plot: Lateral and plant row spacing } \\
\hline $\mathrm{M}_{1}: \operatorname{LS} 80 \mathrm{~cm}(20 \times 10 \mathrm{~cm})$ & 73.9 & 70.4 & 602 & 39.2 \\
\hline $\mathrm{M}_{2}: \operatorname{LS} 80 \mathrm{~cm}(7.5 \times 20 \times 25 \times 20 \times 7.5 \mathrm{~cm})$ & 76.1 & 74.9 & 625 & 39.4 \\
\hline $\mathrm{M}_{3}:$ LS $100 \mathrm{~cm}(20 \mathrm{X} 10 \mathrm{~cm})$ & 73.0 & 65.8 & 571 & 37.5 \\
\hline $\mathrm{M}_{4}: \operatorname{LS} 100 \mathrm{~cm}(7.5 \times 15 \times 15 \times 25 \times 15 \times 15 \times 7.5 \mathrm{~cm})$ & 71.4 & 60.2 & 606 & 37.6 \\
\hline $\mathrm{CD}(\mathrm{P}=0.05)$ & 4.3 & 4.7 & 48 & 1.5 \\
\hline \multicolumn{5}{|l|}{ Sub plot: Fertilizer levels and sources } \\
\hline $\mathrm{S}_{1}: 75 \% \mathrm{RDF}(\mathrm{CF})$ & 70.9 & 59.4 & 544 & 37.0 \\
\hline $\mathrm{S}_{2}: 100 \% \mathrm{RDF}(\mathrm{CF})$ & 73.6 & 71.4 & 634 & 39.1 \\
\hline $\mathrm{S}_{3}: 75 \% \mathrm{RDF}(\mathrm{WSF})$ & 72.1 & 68.8 & 565 & 37.6 \\
\hline $\mathrm{S}_{4}: 100 \% \mathrm{RDF}(\mathrm{WSF})$ & 74.7 & 71.7 & 660 & 40.0 \\
\hline $\mathrm{CD}(\mathrm{P}=0.05)$ & 3.6 & 3.4 & 30 & 1.9 \\
\hline
\end{tabular}

LS- Lateral spacing ; RDF-Recommended dose of fertilizer ; CF-Conventional fertilizers; WSF- Water Soluble fertilizers. 
of optimum soil moisture which permitted the plants to absorb more nutrients. These results are in agreement with the findings of (Reddy and Aruna 2012). Fertigation of $75 \%$ RDF as conventional fertilizers recorded significantly shorter plants (70.9 $\mathrm{cm}$ ), minimum leaves per hill (59.4) and tillers (544 per $\mathrm{m}^{2}$ ) than $100 \%$ RDF.

Leaf chlorophyll content was observed by using SPAD meter at flowering stage and revealed that significantly higher SPAD meter reading was recorded in $80 \mathrm{~cm}$ lateral spacing irrespective of row spacing over $100 \mathrm{~cm}$ lateral spacing. Application of water soluble fertilizers at $100 \%$ RDF showed statistically higher SPAD reading over $75 \%$ RDF either as conventional or water soluble fertilizers. But, it was comparable with $100 \%$ RDF as conventional fertilizers. Higher availability of nitrogen and water under these treatments favoured higher chlorophyll synthesis which led to more SPAD reading.

\section{Root growth characters}

Root characters of rice influenced by lateral spacing, row spacing and nutrient management in drip irrigation during maximum tillering stage (Fig. 1). Significantly higher root length (18.5 $\mathrm{cm})$, root volume $(13.1 \mathrm{cc})$ and root dry weight $(6.2 \mathrm{~g})$ were registered under lateral spacing of 80 $\mathrm{cm}$ with altered row spacing mainly because of higher availability of water to both the rows. This was comparable with same lateral spacing with uniform row spacing except root dry weight. Drip irrigation creates favourable soil physical, chemical and biological properties that support plant growth under mostly aerobic soil conditions, encouraging better root growth parameters. (Stoop et al. 2002). Similarly, Parthasarathi et al. (2013) observed that lateral spacing of $80 \mathrm{~cm}$ and plants spaced at $20 \mathrm{~cm}$ $\times 10 \mathrm{~cm}$ with 1 lph drippers along with sub-surface drip irrigation treatment achieved good root growth of rice. In $100 \mathrm{~cm}$ lateral spacing, uniform row spacing produced higher root length and volume over modified row spacing. Presence of closer spacing and more number of rows under $100 \mathrm{~cm}$ lateral spacing with modified row spacing caused lesser root length and volume. Lower root growth parameters of rice were noticed with $100 \mathrm{~cm}$ lateral spacing in modified row spacing.

Among the nutrient management practices, 100\% RDF as soluble fertilizers produced statistically higher root length $(16.4 \mathrm{~cm})$, root volume $(11.5 \mathrm{cc})$ and root dry weight (5.6 g/plant) than $75 \% \mathrm{RDF}$ irrespective sources at maximum tillering stage. This is mainly because application of fertlizers through drip irrigation resulted in continuous supply of nutrients besides maintaining optimum water availability which leads to higher root growth parameters of rice. Significant difference has not been noticed between water soluble and conventional fertilizers in terms of root growth. Fertigation of $75 \%$ RDF produced lesser root growth parameters of rice. Minimum root volume (9.2 cc) and dry weight $(4.6 \mathrm{~g} /$ plant $)$ were obtained with fertigation of $75 \%$ RDF as conventional fertilizers.

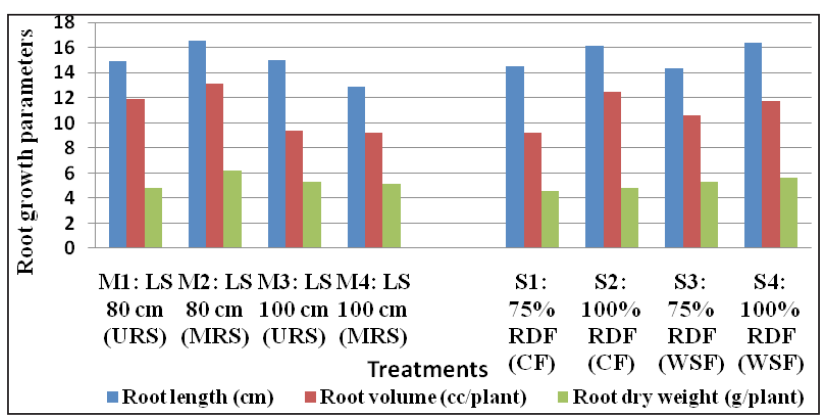

Fig. 1: Effect of lateral, plant row spacing, fertilizer levels and sources on root growth parameters of drip irrigated rice

\section{Yield characters}

Yield characters of rice altered favourably by the lateral, row spacing spacing and nutrient management practices (Table 2). Lateral spacing of $80 \mathrm{~cm}$ recorded significantly more number of productive tillers $\left(453 / \mathrm{m}^{2}\right)$ and number of filled grains per panicle (124.9) under modified row spacing $(7.5 \times 20 \times 25 \times 20 \times 7.5 \mathrm{~cm})$ than lateral spacing of $100 \mathrm{~cm}$ irrespective of plant row spacing. However, this treatment was comparable with lateral spacing of $80 \mathrm{~cm}$ coupled with uniform row spacing in number of filled grains per panicle. The reasons for higher yield attributes may be due to the continuous supply of required quantity of water and nutrients below the root zone of the crop. This result is in conformity with the findings of Vanitha and Mohandass, (2014). Minimum number of productive tillers was registered in $100 \mathrm{~cm}$ lateral spacing with uniform row spacing. In case of filled grains, $100 \mathrm{~cm}$ lateral spacing with modified row spacing recorded minimum number of filled grains mainly due to poor lateral movement of irrigation water created water stress at the root zone rows 
Table 2: Effect of lateral, plant row spacing, fertilizer levels and sources on yield parameters, grain yield and water productivity of drip irrigated rice

\begin{tabular}{|c|c|c|c|c|c|}
\hline \multirow[b]{2}{*}{ Treatments } & \multicolumn{3}{|c|}{ Yield parameters } & \multirow[b]{2}{*}{$\begin{array}{l}\text { Grain yield } \\
(\mathrm{Kg} / \mathrm{ha})\end{array}$} & \multirow[b]{2}{*}{$\begin{array}{l}\text { Water } \\
\text { productivity } \\
(\mathrm{kg} / \mathrm{ha} / \mathrm{mm})\end{array}$} \\
\hline & $\begin{array}{l}\text { Productive } \\
\text { tillers } \\
\text { No./m² }\end{array}$ & $\begin{array}{l}\text { Filled } \\
\text { grains/ } \\
\text { panicle }\end{array}$ & $\begin{array}{l}\text { Ill filled } \\
\text { grains/ panicle }\end{array}$ & & \\
\hline \multicolumn{6}{|l|}{ Main plot: Lateral and plant row spacing } \\
\hline $\mathrm{M}_{1}: \mathrm{LS} 80 \mathrm{~cm}(20 \times 10 \mathrm{~cm})$ & 417 & 116.4 & 24.0 & 4721 & 3.41 \\
\hline $\mathrm{M}_{2}: \operatorname{LS} 80 \mathrm{~cm}(7.5 \times 20 \times 25 \times 20 \times 7.5 \mathrm{~cm})$ & 453 & 124.9 & 19.6 & 5055 & 3.65 \\
\hline $\mathrm{M}_{3}:$ LS $100 \mathrm{~cm}(20 X 10 \mathrm{~cm})$ & 380 & 101.6 & 23.5 & 3154 & 2.28 \\
\hline $\mathrm{M}_{4}: \operatorname{LS} 100 \mathrm{~cm}(7.5 \times 15 \times 15 \times 25 \times 15 \times 15 \times 7.5 \mathrm{~cm})$ & 410 & 84.6 & 30.7 & 2911 & 2.10 \\
\hline $\mathrm{CD}(\mathrm{P}=0.05)$ & 33 & 8.6 & 2.0 & 305 & 0.3 \\
\hline \multicolumn{6}{|l|}{ Sub plot: Fertilizer levels and sources } \\
\hline $\mathrm{S}_{1}: 75 \% \mathrm{RDF}(\mathrm{CF})$ & 383 & 102.5 & 24.9 & 3656 & 2.64 \\
\hline $\mathrm{S}_{2}: 100 \% \mathrm{RDF}(\mathrm{CF})$ & 445 & 107.1 & 23.3 & 4107 & 2.96 \\
\hline $\mathrm{S}_{3}: 75 \% \mathrm{RDF}(\mathrm{WSF})$ & 382 & 103.9 & 24.4 & 3847 & 2.78 \\
\hline $\mathrm{S}_{4}: 100 \%$ RDF (WSF) & 450 & 114.1 & 25.2 & 4230 & 3.05 \\
\hline $\mathrm{CD}(\mathrm{P}=0.05)$ & 29 & 10.7 & 1.5 & 346 & 0.2 \\
\hline
\end{tabular}

LS- Lateral spacing ; RDF- Recommended dose of fertilizer; CF- Conventional fertilizers; WSF- Water Soluble fertilizers.

away from the lateral during the cropping period. Among the nutrient management practices, water soluble fertilizer at $100 \%$ recommended dose registered more number of productive tillers (450/ $\mathrm{m}^{2}$ ) and number of filled grains per panicle (114.1) over lower dose of fertilizer. There was not much variation in yield attributes due to fertilizer sources in both levels.

Number of ill filled grains was more in $100 \mathrm{~cm}$ lateral spacing with modified row spacing(30.7) mainly due to poor soil moisture and more number of rows per lateral (six rows), followed by lateral spacing $80 \mathrm{~cm}$ with uniform plant row spacing (24.0). Minimum number of ill filled grains (19.6) was noticed in lateral spacing of $80 \mathrm{~cm}$ with modified row spacing over other treatments. Presence of adequate soil moisture in all the rows under modified row spacing favoured better grain filling. Lesser number of ill filled grains per panicle (23.3) was noticed with $100 \%$ RDF as conventional fertilizers than $100 \%$ RDF as water soluble fertilizers. This was followed by application of $75 \%$ RDF as water soluble fertilizers (24.4). More number of ill filled grains per panicle (25.2) was obtained with $100 \%$ RDF as soluble fertilizers.

\section{Grain yield}

Grain yield of rice was positively influenced by different lateral, row spacing and nutrient management under drip irrigation (Table 2). Significantly higher grain yield of $5055 \mathrm{~kg} / \mathrm{ha}$ was obtained with lateral spacing of $80 \mathrm{~cm}$ and modified row spacing $(7.5 \times 20 \times 25 \times 20 \times 7.5 \mathrm{~cm})$ than other treatments. Alteration of plant row spacing brought the second row closer to the lateral $(30 \mathrm{~cm}$ in uniform spacing and $22.5 \mathrm{~cm}$ in modified row spacing) caused higher availability of soil moisture in the root zone of all the four rows present in between the laterals at regular interval favoured better crop growth, yield attributes and grain yield in this treatment. The amount of water supplied with drip irrigation which is sufficient to saturate the soil during reproductive stage resulting in better spikelet fertility and finally the yield. Similar trend was observed by Sritharan et al. (2010), Soman (2012), and Vanitha (2012) on rice. Lateral spacing of $80 \mathrm{~cm}$ with uniform plant row spacing $(20 \times$ $10 \mathrm{~cm}$ ) recorded grain yield of $4721 \mathrm{~kg} / \mathrm{ha}$. The lateral spacing at $100 \mathrm{~cm}$ in both regular as well as modified row spacing registered significantly lesser grain yield than $80 \mathrm{~cm}$, mainly due to poor lateral movement of water and lesser availability of soil moisture and nutrients at $100 \mathrm{~cm}$ lateral spacing. In the case of $100 \mathrm{~cm}$ lateral spacing, uniform row spacing registered higher grain yield of $3154 \mathrm{~kg} / \mathrm{ha}$ than modified row spacing ( $2911 \mathrm{~kg} / \mathrm{ha})$.

Among the levels and sources of fertilizer tested in fertigation, application of $100 \%$ recommended 
fertilizer as water soluble fertilizer produced significantly higher grain yield of $4230 \mathrm{~kg} / \mathrm{ha}$ over lesser doses of fertilizers. Drip fertigation with water soluble fertilizers such as MAP and SOP provides the essential nutrients directly to the active root zone, thus minimizing the loss of nutrients which ultimately helps in higher nutrient uptake and improving the productivity of rice. Further, continuous availability of water and nutrients that resulted in higher uptake of nutrients in turn improved grain yield under drip fertigation. Similar findings were reported by Karthika and Ramanathan (2019). This was comparable with application of $100 \%$ fertilizer as conventional fertilizer. Reduction in fertilizer dose $(25 \%)$ recorded lesser yield than $100 \%$ recommended dose of fertilizers in both the sources. Between sources of fertilizers, no significant difference in grain yield was observed.

\section{Water productivity}

Water productivity is an accurate indicator of agricultural productivity in relationship to crop's consumptive use of water. Water productivity of drip irrigated rice positively influenced by lateral spacing, plant row spacing, fertilizer levels and doses. In this field trial, water productivity results reflected exactly the same trend as grain yield. Total water used for rice cultivation under drip irrigation at $150 \%$ pan evaporation was $1386 \mathrm{~mm}$ during cropping season. Higher water productivity of $3.65 \mathrm{~kg} / \mathrm{ha} / \mathrm{mm}$ of water was obtained under $80 \mathrm{~cm}$ lateral with modified row spacing mainly because of higher grain yield under this treatment due to uniform wetting. Similarly, improved water productivity of aerobic rice was achieved under drip irrigation as compared to flooded rice (Grassi et al. 2009). Lateral spacing of 100 $\mathrm{cm}$ recorded lesser water productivity over 80 $\mathrm{cm}$ spacing. Between fertilizer levels, $100 \%$ RDF produced higher water productivity over $75 \%$ RDF. Water soluble fertilizers recorded increased water productivity over conventional fertilizers. Higher water productivity was mainly due to higher grain yield obtained under these treatments.

\section{CONCLUSION}

From the present field investigation on drip fertigation for hybrid rice, it could be concluded that growing of hybrid rice CORH 3 under drip irrigation using $80 \mathrm{~cm}$ lateral spacing, modified row spacing $(7.5 \times 20 \times 25 \times 20 \times 7.5 \mathrm{~cm})$ and fertigation of $100 \%$ recommended dose of fertilizers either as conventional or water soluble fertilizers found to increase the productivity of hybrid rice.

\section{ACKNOWLEDGEMENTS}

The authors are grateful to acknowledge the financial support given by the Netafim Irrigation India Pvt. Ltd., to carry out this research at Tamil Nadu Rice Research Institute, Tamil Nadu Agricultural University, Aduthurai-612 001, Tamil Nadu, India

\section{REFERENCES}

Anon. 2016. Agricultural Statistics at a glance-Directorate of Economics and Statistics, Govt. of India, New Delhi.

Anusha, S. and Nagaraju. 2015. Performance of rice genotypes under drip irrigation in comparison with aerobic and puddled transplanted condition. Mysore J. of Agril. Sci., 49(2): 193-197.

Assouline, S. 2002. The effects of microdrip and conventional drip irrigation on water distribution and uptake. Soil Sci. Soc. Am. J., 66: 1630-1636.

Barker, R., Dawe, D. Tuong, TP, Bhuiyan, SI, and Guerra, LC. 1999. The outlook for water resources in the year 2020: challenges for research on water management in rice production. In: International Rice Commission Newsletter No. 49. DV Tran (Ed.) Food and Agriculture Organization of the United Nations. Rome, Italy.

Belder, P., Bouman, BA, Spiertz, JH, Lu, G. and Quilang, EJ. 2002. Water use of alternately submerged and nonsubmerged irrigated lowland rice. Water-Wise Rice Production. IRRI, Los Baños, Philippines, pp. 51-61.

Belder, P., Bouman, B.A.M, Cabangon, R. Lu, G., Quilang, E.J.P, Li, Y., Spiertz, J.H.J. and Tuong, T.P. 2004. “Effect of water-saving irrigation on rice yield and water use in typical lowland conditions in Asia," Agric. Water Manage. 65(3): 193-210.

Eid, A.R., Bakry, B.A. and Taha, M.H. 2013. Effect of pulse drip irrigation and mulching systems on yield, quality traits and irrigation water use efficiency of soybean under sandy soil conditions. Agricultural Sciences, 5: 249-261.

Gomez, K.A. and Gomez, A.A. 1984. Statistical Procedures for Agricultural Research. $2^{\text {nd }}$ Edn., John Wiley and Sons, UK.

Wang, Z., Zuoxin, L, Zikunand, Z. Xingbin, L. 2009. Subsurface drip irrigation scheduling for cucumber (Cucumis satious L.) grown in solar greenhouse based on $20 \mathrm{~cm}$ standard pan evaporation in Northeast China, Scientia Horticulturae, 123(1): 51-57.

Grassi, Chiara, Bouman, Bas, CastaÃeda, Ambrocio, Manzelli, Marco and Vecchio, Vincenzo. 2009. Aerobic rice: Crop performance and water use efficiency. J. Agri. Env. Int. Dev., 103. 10.12895 /jaeid.20094.35. 
Hanson, B. and May, D. 2000. Drip irrigation increases tomato yields in salt-affected soil of San Joaquin Valley. California Agriculture, 57: 132-137.

Karthika, N. and Ramanathan, S.P. 2019. Effect of drip fertigation on growth, physiological parameters and grain yield of rice grown in Cauvery new delta zone of Tamil Nadu. International Journal of Chemical Studies, 7(3): 2758-2761.

Medley, J. and Wilson, L. T. 2005. The use of sub-surface drip irrigation for rice. In: Proceeding of the $10^{\text {th }}$ National Convention System on Cotton and Rice Conference, Texas, USA, pp. 33-34.

Ottis, B., Henggeler, J. and Vories, E.D. 2006. Low-pressure, subsurface drip-irrigation for rice. ASA-CSSA-SSSA Annual Meeting [abstracts]. November 12-16, Indianapolis, Indiana. unpaginated CD-ROM.

Parthasarathi, T., Mohandass, S., Senthilvel, S. and Vered, E. 2013. Effect of drip irrigation systems on yield of aerobic rice. Environment \& Ecology, 31: 1826 - 1829.

Reddy BS, Aruna E. 2009. Effect of irrigation levels through drip on growth, yield and quality of cotton. Journal of Cotton Research and Development, 23(1): 56-9.
Soman, P. 2012. Drip fertigation for rice cultivation, In: Proc. Asian Irrigation Forum, 11-12 April, 2012, ADB, Manila, Philippines.

Sritharan, N., Vijayalakshmi, C., and Selvaraj, P.K. 2010. Effect of micro-irrigation technique on physiological and yield traits in aerobic rice. Int. J. Agric. Environ. \& Biotech. 3: 26-28.

Stoop, W.A., Uphoff, N., Kassam, A. 2002. A review of agricultural research issues raised by the system of rice intensification (SRI) from Madagascar: Opportunities for improving farming systems for resource poor farmers. Agric. Systems, 71: 249-274.

Vanitha K, and Mohandass S. 2014. Effect of humic acid on plant growth characters and grain yield of drip fertigated aerobic rice (Oryza sativa L.). The Bioscan., 9(1): 45-50.

Vanitha, K. 2012. Physiological comparison of surface and subsurface drip systems in irrigating aerobic rice (Oryza sativa L.). Unpublished thesis of the Department of crop physiology, Tamil Nadu Agricultural University, India. 
